\title{
SISTEM INFORMASI \\ PENJUALAN DAN PENGHITUNGAN KADAR PERHIASAN EMAS (STUDY KASUS DI TOKO PERHIASAN REJEKI DENPASAR - BALI)
}

\author{
Ali Mahmudi ${ }^{1}$, Sandy Nataly Mantja ${ }^{2}$, Dias Alfan Fernanda ${ }^{3}$ \\ 1amahmudi@hotmail.com, ${ }^{3}$ fallen.dias@gmail.com \\ Teknik Informatika, Institut Teknologi Nasional Malang
}

\begin{abstract}
Abstrak- Perhiasan emas dan perak, dari dulu sampai sekarang, sudah menjadi gaya hidup di masyarakat. Perhiasan dipakai sebagai penunjang penampilan maupun sebagai alat investasi. Dalam perkembanganya perhiasan dapat terbuat dari campuran bahan logam mulia seperti tembaga, perak dan emas. Sistem informasi ini dirancang untuk membantu proses penjualan di Toko Perhiasan Rejeki Denpasar-Bali. Applikasi ini dibuat dengan menggunakan Microsoft Visual Studio 2008, database MySql dan MySql konector 6.1.3 sebagai konektor.

Sistem informasi ini dilengkapi dengan aplikasi untuk menghitung kadar perhiasan. Di samping itu, aplikasi ini juga dilengkapi denganalat hitung untuk menentukan campuran emas, perak dan tembaga untuk membuat emas dengan kadar tertentu. Metode gosok batu adalah metode tradisional untuk mengetahui kadar perhiasan. Metode ini dilakukan dengan cara menggosokan perhiasan ke batu dan kemudian ditambahkan cairan kimia. Metode ini kurang akurat untuk menentukan kadar perhiasan. Oleh sabab itu, dibangunlah sistem informasi penjualan dan penghitungan kadar perhiasan.

Aplikasi ini diharapkan dapat mempermudah dalam pendataan penjualan dan pesanan perhiasan di Toko perhiasan Rejeki Denpasar-Bali.
\end{abstract}

Kata Kunci: Sistem Informasi Penjualan, Emas, aplikasi hitung kadar, perhiasan.

\section{i Pendahuluan}

\section{A. LATAR BELAKANG}

Perhiasan atau logam mulia, dapat terbuat dari campuran perak, tembaga dan emas. Banyaknya jenis perhiasan dan bermacam jenis campuran logam yang terdapat di dalam perhiasan, membuat kebanyakan toko perhiasan mengalami kesulitan untuk menentukan kadar perhiasan. Apalagi jika perhiasan yang dijual kepada pelanggan adalah perhiasan emas. Emas di Indonesia adalah hasil produksi PT. Aneka Tambang dengan kadar hingga 99,99\%.

Untuk mengetahui kadar perhiasan secara tradisional, dengan cara menggosokkan perhiasan ke batu dicampur dengan cairan kimia berbahaya, yang biasa disebut dengan metode gosok batu. Metode ini kurang akurat untuk menentukan kadar perhiasan. Maka dibangunlah sistem informasi penjualan dan penghitungan kadar perhiasan emas.

Pada umumnya, toko penjual perhiasan menggunakan buku besar untuk mencatat data stok dan barang yang telah di jual. Untuk lebih mempermudah proses penjualan perhiasan, maka dibuat aplikasi sistem penjualan perhiasan yang dapat menyimpan data stok perhiasan serta data perhiasan yang telah terjual secara komputerisasi menggunakan aplikasi Visual Studio.Net 2008. Dengan menggunakan aplikasi ini, diharapkan dapat mempermudah toko perhiasan dalam proses penjualan perhiasan dan dalam penghitungan kadar perhiasan. 


\section{B. EMAS}

\section{Nama asli 79}

Berat Jenis

Titik lebur

: $1063^{\circ} \mathrm{C}$

Titik didih

: $2600^{\circ} \mathrm{C}$

Emas merupakan barang bernilai tinggi dan dapat dipergunakan sebagai perhiasan, bahan industry dan bahkan sebagai barang investasi. Perhiasan emas banyak di minati oleh semua strata lapisan masyarakat. ${ }^{[5,6]}$

Emas adalah logam lunak, lenting dan mudah ditempa, emas juga konduktor yang baik. Logam ini tidak aktif secara kimiawi dan tahan karat. Emas sering terdapat bebas di endapan sungai, urat kuarsa, atau dari pirit. Emas juga dimungkinkan terdapat pada bijih besi atau perak, tembaga, timbal, nikel, dan tellurium. Symbol kimia dari emas yaitu Au. ${ }^{[5]}$

Karena emas murni sangat lunak, maka perhiasan emas dicampur dengan logam lain untuk mencapai kekerasan, warna, dan titik leleh yang diinginkan. Perak dan tembaga adalah dua logam yang paling umum digunakan untuk campuran emas. ${ }^{[5]}$ Dua unsur logam atau lebih dapat digabungkan menjadi logam campuran. Ini dilakukan untuk mengubah ciri visualnya seperti warna, atau untuk meningkatkan kekerasan, kepadatan, tahan korosi / tahan karat, atau yang lainnya. Pemanasan dan peleburan digunakan untuk mencampur dan menyatukan komponen-komponennya. Logam campuran dengan logam mulia masih dapat dianggap sebagai "logam mulia" selama perbandingan bakunya tetap dipertahankan dan logam mulianya masih mendominasi. ${ }^{[5]}$

\section{PERANCANGAN}

Perancangan sistem informasi penjualan dan penghitungan kadar perhiasan di tunjukan dengan diagram alir pada Gambar 1-5.

\section{Diagram alir menu data stok}

Pada diagram alir menu stok perhiasan yang berisikan 4 menu yaitu entry data stok, proses data stok, tampilkan data stok dan keluar. Diagram ini ditunjukkan pada Gambar1.

Tabel 1. Standar Kadar Emas

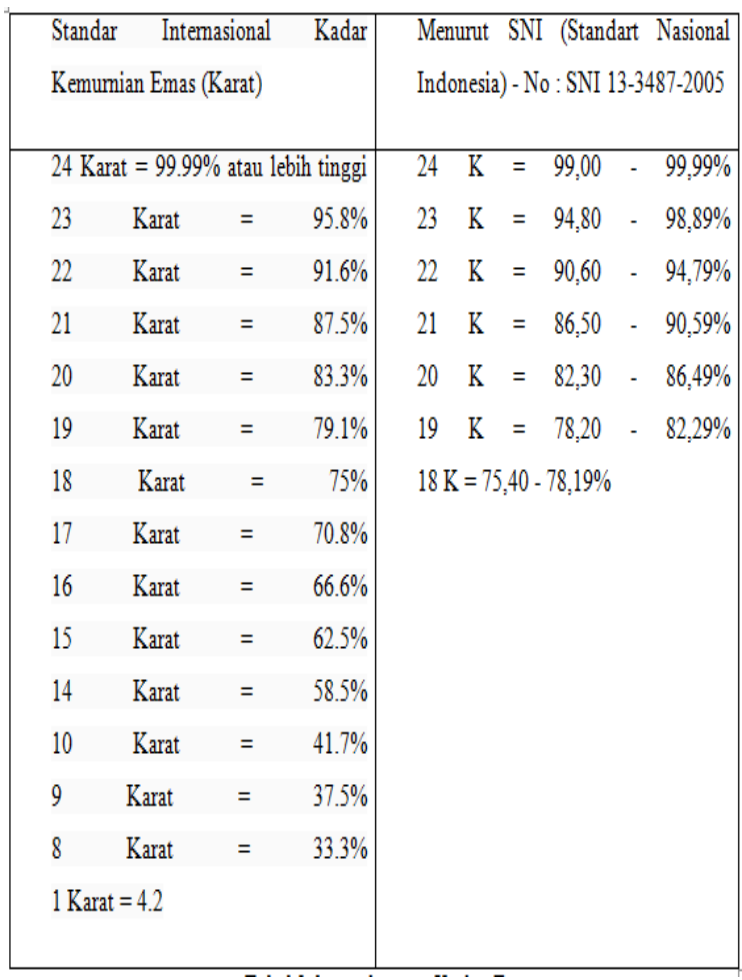

Tabel 2. Campuran logam mulia

\begin{tabular}{|l|r|l|r|r|r|c|}
\hline & & Emas & Perak & Tembaga & Platina & Paladium \\
\hline Perak & $935 * *$ & - & $93,5 \%$ & $6,5 \%$ & - & - \\
\hline Emas Kuning & $18 \mathrm{~K}=750$ & $75 \%$ & $12,5 \%$ & $12,5 \%$ & - & - \\
\hline Emas Kuning & $14 \mathrm{~K}=585$ & $58,5 \%$ & $20,5 \%$ & $21 \%$ & - & - \\
\hline Emas Merah & $18 \mathrm{~K}=750$ & $75 \%$ & - & $25 \%$ & - & - \\
\hline Emas Putih & $18 \mathrm{~K}=750$ & $75 \%$ & - & - & - & $25 \%$ \\
& & & & & & \\
\hline
\end{tabular}


Tabel 3. Berat jenis berdasarkan SNI (Standart Nasional Indonesia) - No : SNI 13-3487-

2005

\begin{tabular}{|l|l|l|l|}
\hline karat & Campuran tembaga & Campuran perak & Campuran perak dan tembaga \\
\hline 23 & 18,43 & 18,68 & 18,55 \\
\hline 22 & 17,61 & 18,06 & 17,83 \\
\hline 21 & 16,84 & 17,49 & 17,17 \\
\hline 20 & 16,16 & 16,94 & 16,55 \\
\hline 19 & 15,53 & 16,44 & 15,98 \\
\hline 18 & 14,94 & 15,96 & 15,45 \\
\hline 17 & 14,39 & 15,50 & 14,94 \\
\hline 16 & 13,88 & 15,08 & 14,48 \\
\hline 15 & 13,41 & 14,67 & 14,04 \\
\hline 14 & 12,96 & 14,29 & 13,62 \\
\hline 13 & 12,56 & 13,93 & 13,25 \\
\hline 12 & 12,12 & 13,58 & 12,85 \\
\hline 11 & 11,80 & 13,25 & 12,52 \\
\hline 10 & 11,46 & 12,94 & 12,20 \\
\hline 9 & 11,14 & 12,64 & 11,89 \\
\hline 8 & 10,83 & 12,36 & 11,60 \\
\hline 7 & 10,54 & 12,08 & 11,31 \\
\hline 6 & 10,26 & 11,82 & 11,04 \\
\hline 5 & 10,00 & 11,57 & 10,78 \\
\hline 4 & 9,77 & 11,33 & 10,54 \\
\hline 3 & 9,52 & 11,10 & 10,31 \\
\hline 2 & 9,29 & 10,88 & 10,08 \\
\hline 1 & 9,08 & 10,67 & 9,87 \\
\hline & & & \\
\hline & & & \\
\hline & & & \\
\hline & & & \\
\hline
\end{tabular}

Tabel 3 di susun berdasarkan macam logam campuranya, yaitu : campuran logam tembaga, campuran perak atau campuran tembaga dan perak. ${ }^{[6]}$

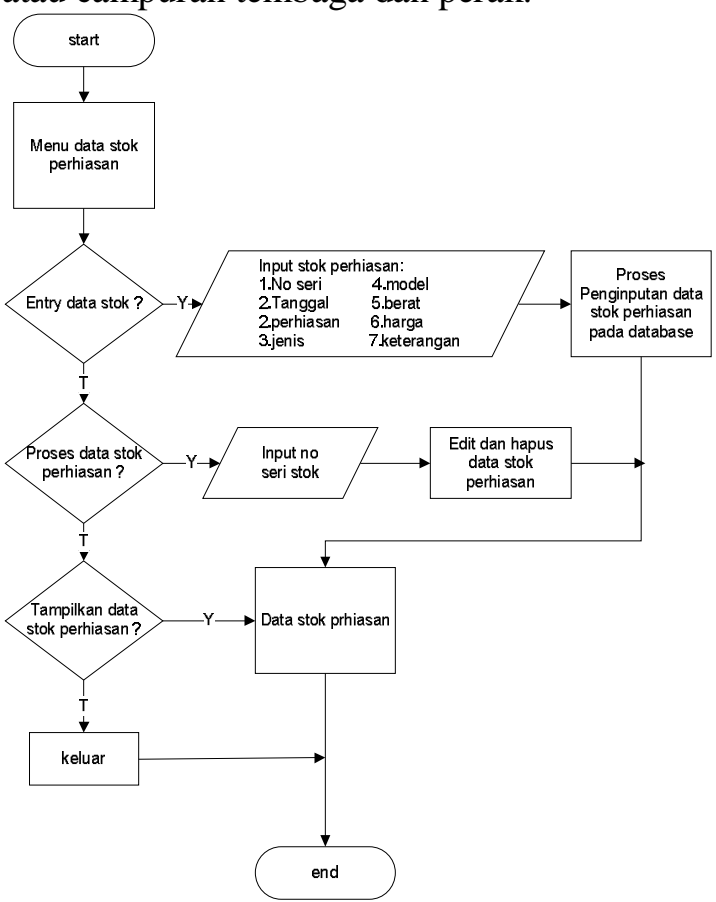

Gambar 1. Menu data stok

\section{Diagram alir menu pesanan}

Pada diagram alir menu data pesanan yang berisikan 4 menu yaitu entry data pesanan, pengambilan pesanan, tampilkan data pesanan dan keluar. Diagram ini ditunjukkan pada gambar 2 berikut ini.

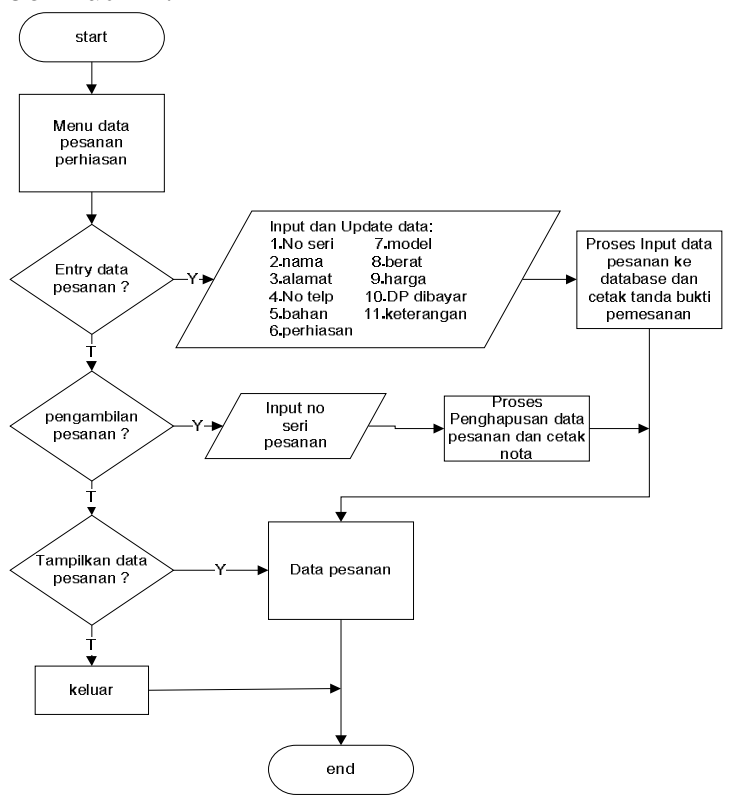

Gambar 2. Menu data pesanan

\section{Diagram alir menu penjualan}

Saat terjadi pembelian perhiasan maka dilakukan proses pengecekan no seri, yang kemudian digunakan untuk memanggil data stok perhiasan yang akan di jual. Diagram ini ditunjukkan pada gambar 3 berikut ini.

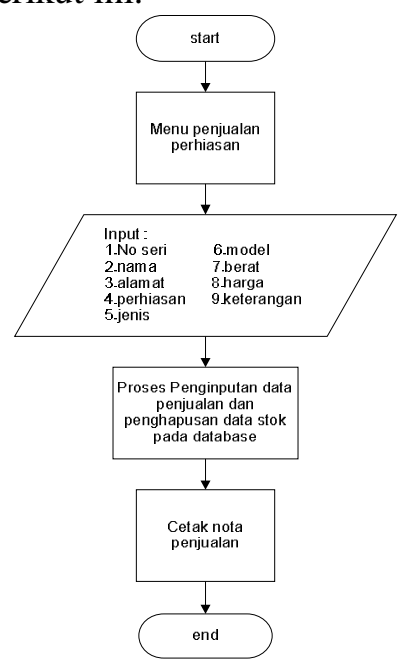

Gambar 3. Menu data pembelian

\section{Diagram alir menu hitung kadar}

Di dalam menu hitung kadar, terdapat menu untuk memasukan hasil timbang normal dan timbang air. Dua nilai ini akan diproses untuk mendapatkan hasil 
kadar perhiasan seperti ditunjukkan pada gambar 4 berikut ini.

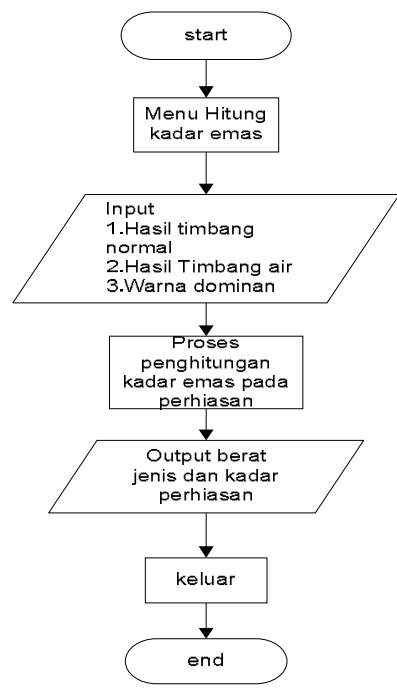

Gambar 4. Menu hitung kadar

\section{Diagram alir menu ubah kadar}

Di dalam diagram alir menu ubah kadar, terdapat 3 pengisian data yaitu berat emas murni, kadar yang diinginkan dan warna dominan yang diinginkan. Hal ini ditunjukkan pada gambar 5 berikut ini.

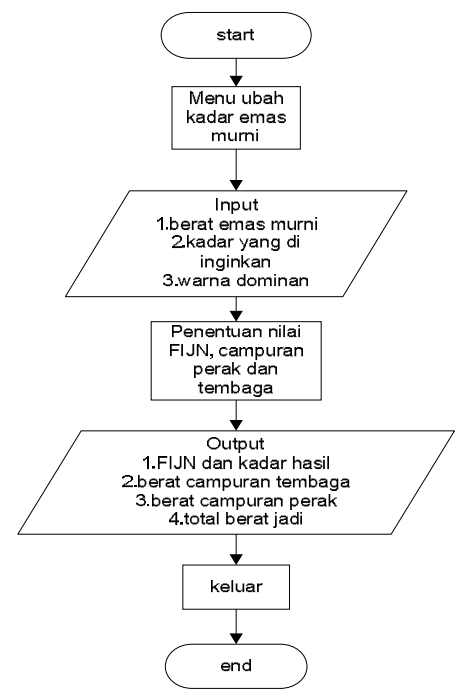

Gambar 5. Menu ubah kadar

\section{Perancangan Database}

\section{a. DFD level 0}

DFD level 0 menjelaskan jalannya sistem informasi penjualan dan pemesanan perhiasan. ${ }^{[3]}$

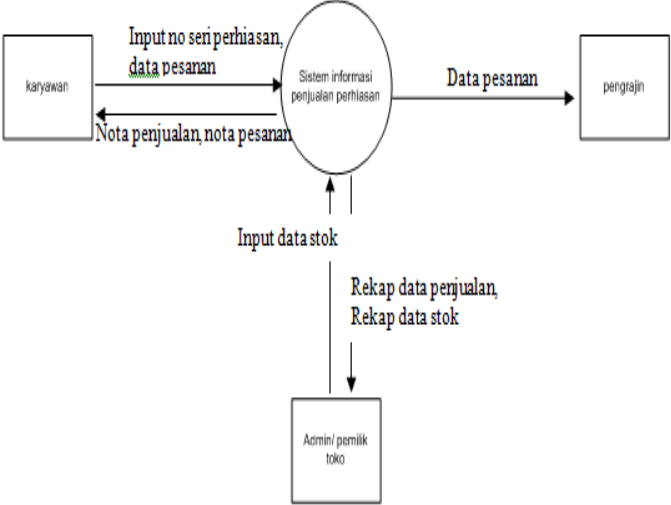

Gambar 6. DFD level 0

\section{b. DFD level 1}

DFD level 1 merupakan alur sistem yang lebih spesifik dari DFD level 0 dimana didalamnya terdapat penjelasan lebih detail. $^{[3]}$

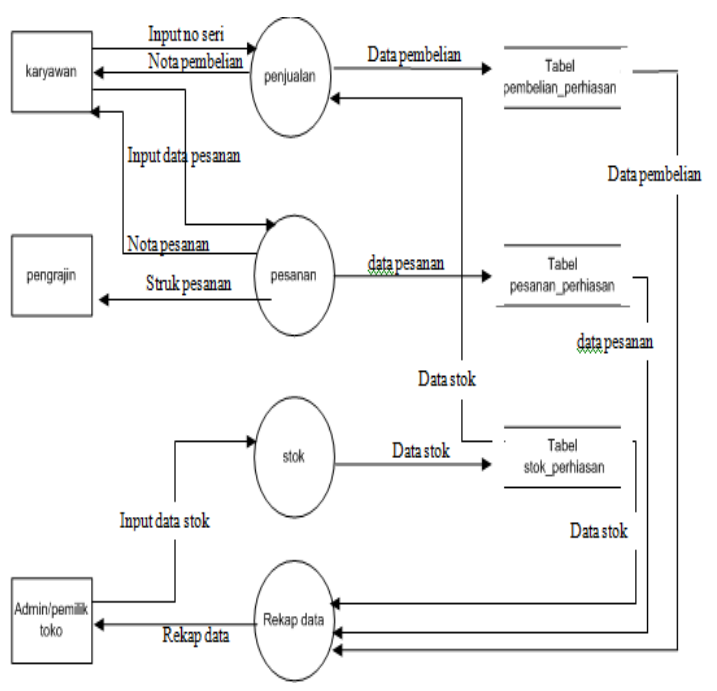

Gambar 7. DFD level 1

\section{c. Entity relationship diagram (ERD)}

ERD merupakan penjelasan dari relasi tabel yang terdapat dalam database sistem informasi penjualan perhiasan.

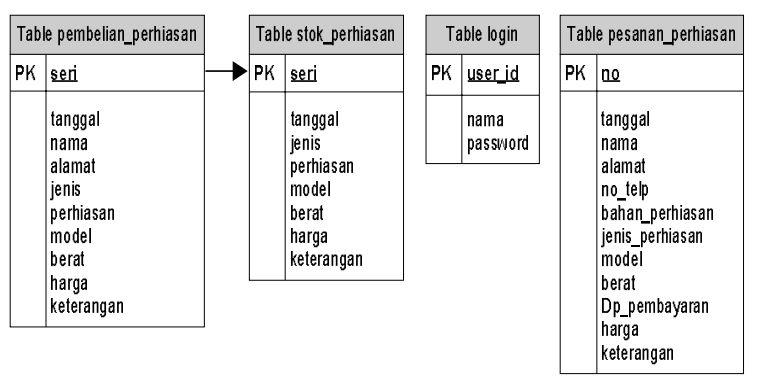

Gambar 8. ERD 
II.

IMPLEMENTASI \& PENGUJIAN

\section{A. Implementasi User Interface}

Pada tampilan user interface ini dibuat sedemikian rupa agar bisa digunakan dengan mudah oleh pengguna. Tampilan user interface ini dibagi menjadi beberapa bagian, yaitu

\section{Tampilan Menu utama}

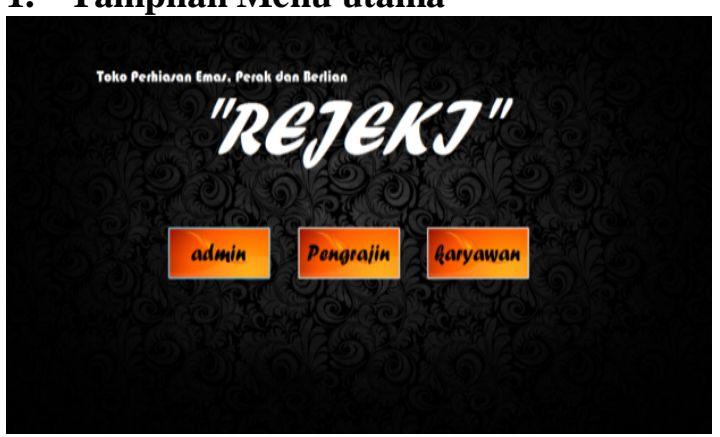

Gambar 9. Menu utama

Ini adalah menu utama yang pertama kali tampil dalam sistem informasi penjualan perhiasan. Dalam menu utama ini terdapat 3 tombol yaitu admin, pengrajin dan karyawan. Setiap tombol login diharuskan memasukan user name dan password.

\section{Tampilan menu hitung karat}

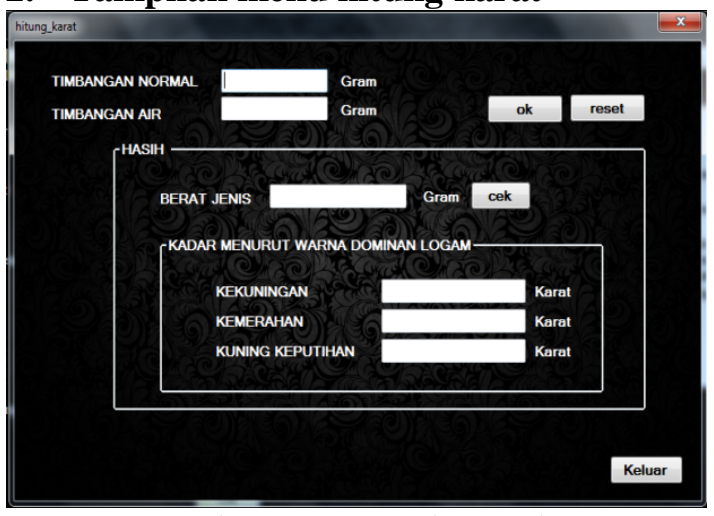

Gambar 10. menu hitung karat

Dalam tampilan hitung kadar karat perhiasan terdapat inputan dari hasil timbangan normal dan hasil timbangn dengan neraca air. Dua inputan ini berikutnya di proses untuk mengetahui berat jenis dan kadar karat perhiasan.
3. Tampilan Menu ubah kadar

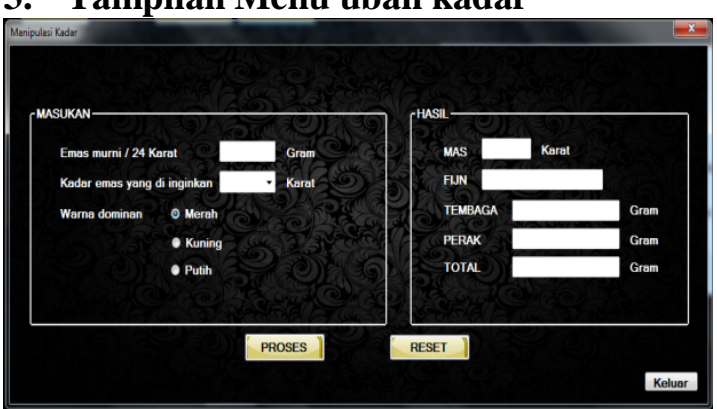

Gambar 11. Menu ubah kadar

Pada tampilan ubah kadar perhiasan berisi tentang inputan berat emas murni dan kadar karatase yang diinginkan. Luaran dari inputan ini adalah campuran perak dan tembaga yang dibutuhkan untuk mencapai kadar karatase yang diinputkan.

\section{B. Pengujian Penghitungan Kadar Perhiasan}

Pengujian perhitungan kadar perhiasan dilakukan dengan membandingkan penghitungan kadar perhiasan secara manual sesuai SNI- 13.3487-2005 dengan penghitungan menggunakan sistem yang telah dibuat.

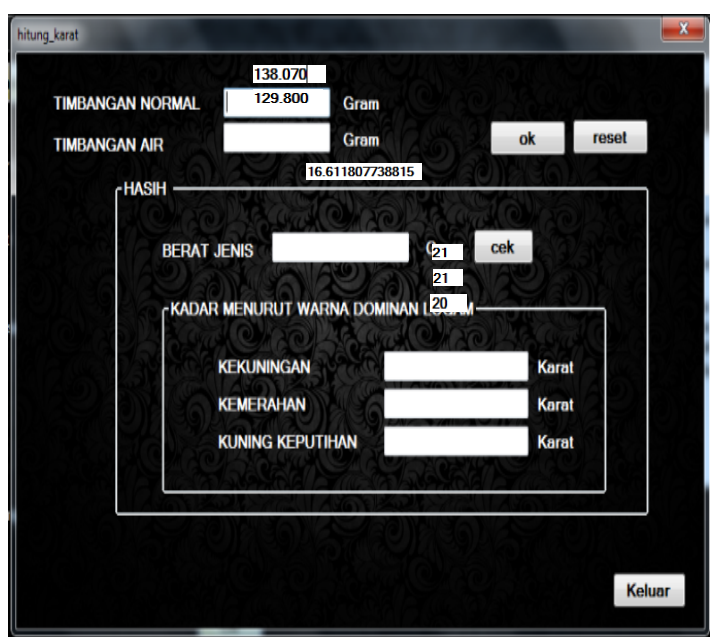

Gambar 12. Tampilan hitung karat pada sistem

Tabel 4. Berat jenis berdasarkan SNI (Standart Nasional Indonesia) - No : SNI 13-3487-2005 


\begin{tabular}{|c|c|c|c|}
\hline Jarat & $\begin{array}{l}\text { Campuran } \\
\text { tembaga } \\
\text { (kemerahan) }\end{array}$ & $\begin{array}{c}\text { Campuran } \\
\text { perak (kuning } \\
\text { keputihan) }\end{array}$ & $\begin{array}{l}\text { Campuran } \\
\text { perak dan } \\
\text { tembaga } \\
\text { (kelzuningan) }\end{array}$ \\
\hline 23 & 18,43 & 18,68 & 18,55 \\
\hline 22 & 17,61 & 18,06 & 17,83 \\
\hline 21 & 16,84 & 17,49 & 17,17 \\
\hline 20 & 16,16 & 16,94 & 16,55 \\
\hline 19 & 15,53 & 16,44 & 15,98 \\
\hline 18 & 14,94 & 15,96 & 15,45 \\
\hline 17 & 14,39 & 15,50 & 14,94 \\
\hline 16 & 13,88 & 15,08 & 14,48 \\
\hline 15 & 13,41 & 14,67 & 14,04 \\
\hline 14 & 12,96 & 14,29 & 13,62 \\
\hline 13 & 12,56 & 13,93 & 13,25 \\
\hline 12 & 12,12 & 13,58 & 12,85 \\
\hline 11 & 11,80 & 13,25 & 12,52 \\
\hline 10 & 11,46 & 12,94 & 12,20 \\
\hline 9 & 11,14 & 12,64 & 11,89 \\
\hline 8 & 10,83 & 12,36 & 11,60 \\
\hline 7 & 10,54 & 12,08 & 11,31 \\
\hline 6 & 10,26 & 11,82 & 11,04 \\
\hline 5 & 10,00 & 11,57 & 10,78 \\
\hline 4 & 9,77 & 11,33 & 10,54 \\
\hline 3 & 9,52 & 11,10 & 10,31 \\
\hline 2 & 9,29 & 10,88 & 10,08 \\
\hline 1 & 9,08 & 10,67 & 9,87 \\
\hline
\end{tabular}

Jika nilai yang diinputkan dari hasil timbang normal adalah 138,070 gram dan timbang air di dapatkan berat 129,800 gram maka berat jenis dari perhiasan tersebut adalah 16,61180. Maka dari berat nilai berat jenis tersebut di ambil kesimpulan jika perhiasan memiliki warna kekuningan berat 21 karat, kemerahan 21 karat dan kuning keputihan 20 karat.

Seperti pada tabel 4 bahwa perhiasan dengan berat jenis 16,61180 maka :

a. memiliki kadar 21 karat pada warna dominan kemerahan karena nilai berat jenis tersebut berada antara nilai 16,16 dan 16,84

b. Memiliki kadar 20 karat pada warna dominan kuning keputihan karena nilai berat jenis tersebut berada antara nilai 16,44 dan 16,94 .

c. Memiliki kadar 21 karat pada warna dominan kekuningan karena nilai berat jenis tersebut berada antara nilai 16,55 dan 17,17 .

Dari perbandingan penghitungan antara Gambar 15 dengan Tabel 4 maka dapat disimpulkan bahwa hasil perhitungan sistem sudah sesuai dengan SNI (Standart Nasional Indonesia) - No : SNI 13-34872005.

\section{KESIMPULAN}

1. Sistem informasi penjualan dan penghitungan kadar perhiasan ini membantu Toko Perhiasan Rejeki dalam mengatur proses jual beli dan pesanan perhiasan.

2. Sistem informasi ini membantu dalam pendataan data stok perhiasan yang telah terjual kepada pelanggan

3. Sistem informasi ini membantu dalam pencarian data pembelian perhiasan jika suatu saat pembeli perhiasan hendak menjual kembali perhiasan yang telah dibeli.

4. Sistem informasi ini memudahkan dalam penghitungan kadar perhiasan dan penentuan campuran logam untuk mencapai kadar emas tertentu.

\section{DAFTAR PUSTAKA}

[1]. Allen G. Tailor. 2003. SQL For Dummies, 5th Edition. Wiley Publishing, Inc.

[2] George Reese. 2003. MySQL Pocket Reference. O'Reilly Publishing.

[3]. Kristanto,Andi. 2010 , Konsep dan perancangan database, Yogyakarta : andi offset

[4] McLeod Raymond, Sistem Informasi Manajemen, Edisi Kedelapan, Prenhallindo, Jakarta, 2004.

[5]. McCreight,Tim; 1986 -;The Complete Metalsmith;Massachusetts: Davis Publcations,Inc.

[6]SNI(Standart Nasional Indonesia) ; 2005 , Barang-barang emas : SNI13.3487-2005 